\title{
THE LOYALTY ORDER'S CHALLENGE TO THE CONSTITUTION
}

\author{
CIIFFORD J. DURR*
}

$\mathrm{I}^{\mathrm{N}}$

N HIS "Memorial and Remonstrance" to the Virginia assembly, issued in $\mathrm{I}^{78}$, James Madison warned that "it is proper to take alarm at the first experiment on our liberties." If his warning is to be taken seriously, there is occasion for grave alarm in the President's Loyalty Order issued March 2I, I947 and in the regulations and directives of the Loyalty Review Board issued pursuant thereto. True, this is not the first "experiment on our liberties" since Madison wrote, but I doubt that there has been any more dangerous in its implications and potentialities. ${ }^{3}$

I am convinced that the evils of the Order far outweigh any possible good that can come from it. It has within it such potentialities of injustice, oppression, and cruelty that its administration will inevitably result in the alienation rather than the promotion of the loyalty of government employees.

While the "standards" list among the tests of loyalty offenses such as espionage, sabotage, treason, etc. (which are already covered by our criminal laws and with which our courts are fully competent to deal), the basic concern of the Order is with attitudes and associations rather than with wrongful behavior - with ideas rather than with deeds. The ultimate determination to be made under the Order is not whether an employee has committed illegal or harmful acts, but whether "reasonable grounds" exist for believing that he is "disloyal."

* Member of the Alabama and Wisconsin Bars; member of the Federal Communications Commission, r94r-48.

${ }_{2}$ Writings of James Madison 185 (Hunt ed., Igor).

2 Executive Order No. 9835, I2 Fed. Reg. I935 (I947).

3 Other authors have also expressed considerable misgivings. See O'Brian, Loyalty Tests and Guild by Association, 61 Harv. L. Rev. 592 (1948); Pike, Witch Hunting Then and Now, 180 Atl. Monthly 93 (Nov. 1947); Cushman, The President's Loyalty Purge, 36 Survey Graphic 283 (May r947); Schlesinger, What Is Loyalty?-A Difficult Question, New York Times Magazine, p. 7 (Nov. 2, 1947). The operation of a loyalty check by the Atomic Energy Commission pursuant to the Atomic Energy Act has also provoked widespread protest. See Miller \& Brown, Loyalty Clearance Procedures of the A.E.C.-A Report and Recommendations, 4 Bulletin of the Atomic Scientists 44 (Feb. I948); Loyalty Clearance Procedures in Research Laboratories, 4 Bulletin of the Atomic Scientists II (Apr. I948). 
Loyalty is a condition of the mind and emotions and, in my opinion, is too subtle a matter to be measured by any such standards as those laid down in the Order, or any which are likely to be laid down under it. I do not believe that men should be officially empowered to sit in judgment on the minds and emotions, or even the associations, ${ }^{4}$ of other men and to judge them by tests short of overt acts or expressions tantamount to overt acts. Lacking any such objective tests, the guide followed will inevitably be the personal opinions and tastes of the judges. Any attempt to punish men for their state of mind or to force their mental processes and conclusions by intimidation rather than to persuade them by reason is as futile as it is wrong. The government may punish or reward acts, it may command obedience; but loyalty, it seems to me, has to be earned.

Faithless as well as incompetent employees should, of course, be removed from their jobs, but the best test of competence and faithfulness, it seems to me, is performance on the job. The Executive Order rejects this test. Instead it sets up a set of subjective standards by which future behavior on the job is to be anticipated. "Reasonable grounds" for "belief" that future performance may be bad, arrived at by the application of these subjective standards, cannot be overcome by a long record of good performance in the past. The verdict turns only on reasonable grounds for "belief" and not upon the preponderance of the evidence. To save his reputation and his job the employee must eradicate all "reasonable grounds" for unfavorable belief even though he may not know, with certainty, what the grounds are. Men are to be known not by the fruits which they have borne, but by prognostications as to the fruits they may bear.

Even if men were given the wisdom always to know with certainty what ideas are good or bad, I doubt the efficacy of intimidation or oppression as a means of stamping out the bad. The expression of ideas may be temporarily silenced, but repression will not destroy them. The only effective weapon against bad ideas is good ideas plus the demonstration of good ideas in action.

The leisurely pace of the administration of the Order, as well as its express provisions, emphasizes its concern with attitudes rather than actions and its futility as a measure of national security. Real dangers call for prompt action. But the Order was issued March 2r, I947. It was not until December I7, I947, nine months later, that the Loyalty Review Board

\footnotetext{
4 For recent judicial pronouncements condemning imputation of guilt on the basis of association, see Bridges v. Wixon, 326 U.S. 135 (I945); Schneiderman v. United States, 320 U.S. II8 (1943) .
} 
issued its first regulations and directives to the government departments and agencies. And in the summer of 1948 , more than a year later, some of the federal agencies wese still giving consideration to the adoption of rules under which their part of the program is to be carried out. The provisions for notice and appeal may serve the ends of fairness, but they are hardly consistent with a reasonable belief in the existence of any "clear and present danger." Moreover, unless it can be assumed that "clearly favorable" findings can be made on all except an inconsequential number of employees, the hearing procedures, even as to employees now on the payroll, will require months for completion. They may require years.

If there are, in fact, "dangerous possibilities involved," as contended by the Chairman of the Loyalty Review Board, then the whole loyalty program had better be scrapped immediately and less cumbersome procedures adopted forthwith to deal with the situation. We cannot afford to temporize when our government is in danger. However, the Federal Communications Commission, for example, operated for more than a year without any loyalty program whatsoever, and I believe its experience is typical of that of many other agencies. So far as I am aware, those in charge of the program did not seek to impress the Commission with the urgency of immediate action. This would seem to indicate that the concern over the "dangerous possibilities," which are cited in justification of the program, is not so great as suggested.

I am convinced that the end result of the Executive Order will be to endanger national security rather than to safeguard it. At a time when confidence in government is of vital importance, the Order tends to destroy confidence by creating fears that the government cannot be trusted because of enemies within its own ranks. By its very provisions the Order officially expresses a lack of confidence in the vigor and effectiveness of those "democratic processes" which it declares to be "the heart and sinew of the United States." It impairs rather than promotes loyalty by departing from those principles of freedom of belief and association and of fair play which, in a democratic society are, and should be, the basis on which loyalty is founded.

It impairs the morale, and therefore the efficiency, of government employees by exposing their reputations and jobs to continuous attack by nameless accusers. It discourages, and in many instances bars, the entry into government service of men of ability, integrity, experience, and imagination, because of their inability to answer unspecific charges of unidentified informers or their unwillingness to subject their reputation 
to the hazards which are now made a part of government service. ${ }^{5}$ It deprives the heads of government agencies and departments of effective control over their own personnel and places in the hands of the Federal Bureau of Investigation a dictatorial power over government employment policies.

It tends to force all political, economic, and social thinking into orthodox patterns at a time when new and unorthodox ideas are desperately needed to cope with new and unorthodox problems. It creates an atmosphere hostile to reason, an atmosphere in which we may be dangerously misled into rejecting information of vital importance solely because it appears to conflict with accepted beliefs of what is so.

The order applies with equal force to all departments and agencies of government, regardless of their functions and responsibilities, and to all employees, regardless of the nature of their work. The typist in the Children's Bureau of the Department of Labor must meet the same test as an employee handling confidential documents in a highly "sensitive" position.

No reasonable person would suggest that the proper way to stamp out robbery in this country is to make suspects of $140,000,000$ American people and examine them all for their criminal tendencies. Reason demands concentration on the immediate sources of danger. The absorption of the police in the major task would enable the real robbers to continue their robbing without great fear of molestation. Yet the Executive Order proposes just such a course with respect to government employees. Two million of them are made "suspects" and must be examined for their "disloyal" tendencies.

If we believe that national security is, in fact, so seriously endangered as to warrant the drastic measures proposed in the Order, can we then afford to stop our crusade for loyalty with government itself? War is no longer the exclusive affair of professional armies or even of the government. Our national security hinges to as great, if not to even greater, an extent upon our mines, factories, mills, and transportation and communications systems. If the "disloyal" clerk in the Fish and Wildlife Service of the Department of the Interior is a threat to security, then is not the "disloyal" worker in a steel mill or automobile factory a far greater threat?

What is to become of the "disloyal" government employee who is dis-

$s$ It is, for example, well known that many scientists have refused to accept work on government sponsored classified projects because of the loyalty checks. See 4 Bulletin of the Atomic Scientists 218 (July r948). 
charged? Is he to be turned loose as a menace to society, to find his way, under an assumed name perhaps, to a job in an airplane plant or an oil refinery? Logic forbids such a course.

If, again, security requires the suppression of dangerous ideas, what about our broadcast stations and networks, with their continuous access to the ears and minds of the American people? What about our newspapers, with their tremendous power of molding public opinion? One of our largest newspapers has been charged with publishing military secrets in time of war, but it is still being published. Can we assume that "disloyal" people have not infiltrated into their ranks? Where can we draw a line consistent with safety?

Even though the principles of the Executive Order are not officially extended beyond government, the example of government will inevitably be followed outside of government. The brand of "disloyalty" will not fade into invisibility once the employee has passed into private life. Moreover, private branding irons are already being made after the government's pattern and more will be made. Can anyone be sure that he will never feel their burn?

We are on the way to creating a new class of outcasts from society-a caste of economic and social "untouchables." This new caste will certainly threaten our security. It will also challenge our humanity. Barred from the normal occupations by which people earn their living, its members will be faced with the alternatives of hunger, an uncertain charity, or crime. Denied the companionship of the clearly "loyal," they will be driven by sheer loneliness into the society of the affirmatively disloyal. If hunger does not make them dangerous, resentment will.

The Executive Order treats rumor and gossip as evidence and shelters it from the test of examination. In the name of security, it raises talebearers and informers to a new level of human dignity, while denying their victims the procedural safeguards guaranteed by our Constitution to the most vicious criminals-including spies, saboteurs, and traitors. By sparing talebearers from the uncomfortable experience of meeting their victims face to face and sheltering them from that public scorn and contempt which has been their traditional lot, it has deprived us of our most effective defense against their mischief. It defies basic religious teachings by giving protection and power to a group against which we are repeatedly warned in both the Old and New Testaments.

By giving official acceptance to rumor and protection to informers, it places in the hand of our enemies effective weapons of psychological warfare to be used against us. The role of "confidential informer" is a 
most convenient one for the enemy agent having the assignment of creating fear, distrust, and suspicion and undermining morale.

It purports to serve our "democratic processes" by ignoring the principle that men should be deemed innocent until their guilt is proved; by denying the right of public trial before an impartial tribunal; by withholding from those accused full information as to the nature and cause of the accusations; by denying to those accused the right to be confronted by their accusers; by failing to extend to them the benefit of compulsory process for obtaining witnesses in their favor; and by authorizing their conviction on unsworn testimony of unknown witnesses. It indicts men for their associations and convicts them on speculations as to their state of mind.

It vests in the Attorney General the authority, by unreviewable decree, issued on the basis of ex parte and secret investigations, to proscribe groups and organizations. It gives our secret police jurisdiction over our beliefs and associations and accepts their accusations in secret without oath or cross-examination. Such a course is as dangerous to liberty in the United States as in Germany, Japan, Italy, or Russia. We have less excuse than they for taking it. We have a different tradition and we also have the warning of their experience.

Those who are accused are to be tried, moreover, not by judges dedicated to impartiality but by men "personally responsible for an effective program to assure that disloyal officers or civilian employees are not to be retained in employment." The judges acquit at their personal peril, for they themselves may be brought to account for their acquittals. They are assigned the role of judges but are accountable as prosecutors.

To require men to hazard their reputations and their means of livelihood upon a hearing before a forum so constituted and applying such standards, in my opinion, makes a mockery not only of "due process" but of elementary standards of fairness.

The justification given by the Chairman of the Loyalty Review Board for the denial to government employees of the basic rights and procedural safeguards guaranteed by the Constitution to all others is that "legally, the government is entitled to discharge any employee for reasons which seem sufficient to the government, and without extending to such employee any hearing whatsoever." I doubt that the government's right in this respect is as free of legal limitation as the Chairman of the Loyalty Review Board contends. Even if we assume that the government may discharge its employees for reasons which are wholly arbitrary, may it discharge them for reasons which are wholly unconstitutional? May it, 
for example, discharge an employee solely because of his religion, or because he has exercised his constitutional right of free speech or participated in peaceable assembly under circumstances and for purposes wholly unconnected with his job?

A finding of "disloyalty" is considerably more than a matter of hiring and firing. It is "punishment" in the truest sense of the word and, under the standards of the Order, may be punishment for activities which are entirely legal and which cannot be made illegal under our Constitution as it now stands.

If the Supreme Court correctly interpreted the Constitution in United States v. Lovett, ${ }^{6}$ then the purposes, as well as the procedures, of the Executive Order are wholly unconstitutional.

In the Loveti case the issue before the court was the validity of a federal statute prohibiting compensation to three named individuals by any governmental agency. The trio had been found guilty by a congressional committee of "subversive" beliefs and "subversive" associations. The Supreme Court held that the statute barred the plaintiffs from government service and that "this permanent proscription from any opportunity to serve the government is punishment." " It is the type of punishment," the court declared, "which Congress has only invoked for special types of odious and dangerous crimes such as treason ... acceptance of bribes by members of Congress... and interference with elections by army and navy officers." "The Court ruled that the act inflicted punishment for activities which were entirely legal and that it accordingly constituted a "bill of attainder" in contravention of Section 9, Article I of the Constitution.

It is true that "bills of attainder" are ordinarily associated with legislative action. But is not the Chief Executive as much bound by constitutional safeguards as is the Congress? It is also true that in the Lovett case the tribunal which conducted the hearing was a committee set up by Congress and not by the President, but the Constitution does not vest judicial power in either of them. Article III vests it in the courts alone. At least Congress has the power, by proper legislative action, to establish courts. The President is not given even this authority.

Separate and apart from the constitutional questions above discussed, Section 2 of Article II of the Constitution does not give the President the complete and unlimited appointive power over government officials and personnel. It expressly provides that "the Congress may by law vest the appointment of such inferior officers, as they think proper, in the Presi-

${ }^{6} 328$ U.S. 303 (I946).

7 Ibid., at 3 I6.

${ }^{8}$ Ibid. 
dent alone, in the Courts of law, or in the heads of departments." Congress has vested in government agencies the appointive power over their own personnel. The President cannot by Executive Order take away a power which Congress itself has constitutionally conferred, nor do I think that he can relieve any such agency of the responsibilities which accompany its appointive power. Unless and until Congress has legislated on this subject, the agencies' responsibility cannot be shifted to the Loyalty Board or the Loyalty Review Board.

But even if every action proposed by the Executive Order could be sustained in the courts, I do not think that the government should be a party to the denial of basic constitutional rights on narrow legalistic grounds. On the contrary, it seems to me that it should assume leadership in promoting the spirit of the Constitution as well as preserving its letter. Certainly the federal government should not resort to the use of economic and social sanctions to accomplish results which it is forbidden to accomplish through the use of political and judicial sanctions by the very terms of the Constitution. The end result of such a trend, once set under way, is to undermine the rule of law and to replace responsible representative government with government by arbitrary power. Limited by no rule of law, such a government enforces its edicts without regard to the courts, because it uses sanctions which the courts do not recognize.

The responsibility for protecting the Constitution does not lie with any single government official or department. It is shared by all of us. Article VI of the Constitution requires that all executive and judicial officers, as well as members of the legislative bodies, both state and federal, "shall be bound by oath or affirmation, to support this Constitution." All, of course, are not expected to be experts in constitutional law, but when an action is proposed which strikes at the basic structure of our constitutional form of government, I do not think any government official should acquiesce or participate in it until he has given more serious consideration to the constitutional issues involved and obtained the best legal advice available. No official, however highly placed, can absolve another from the responsibility which accompanies his oath of office.

The loyalty program is a new departure in government so far as this country is concerned. It challenges principles which all Americans have been taught since school days to regard as fundamental. The nearest approximation to what is now proposed was the Alien and Sedition Laws, and we repented of them long ago.

At least the Alien and Sedition Laws provided for trials in the duly constituted courts under the procedural safeguards guaranteed by the 
Constitution. The present program seeks to by-pass the courts and the constitutional safeguards by resorting to sanctions which the courts and the Constitution do not recognize. It is thus an even greater danger to our kind of government, for it ignores the "rule of law" and seeks to control people's actions and beliefs by methods outside of the law.

I fully recognize that ideas and associations can be a real source of danger. But the wrong method of fighting them can be an even greater source of danger. A democratic form of government must assume certain calculated risks. If it is unwilling to assume these risks, it ceases to be democratic. Our form of government rests on a base of substantive and procedural laws, the cornerstone of which is the Constitution. We cannot, of course, achieve absolute certainty in the interpretation and enforcement of these laws, and human error must be allowed for. But it is essential that we constantly strive for the nearest approximation of certainty that can reasonably be achieved. For any warping or weakening of the base upon which it rests endangers the structure of government itself. The disregard or perversion of these laws by those charged with responsibility for their administration and enforcement can be "subversive" activity of a most effective and dangerous kind.

\section{LETTER FROM HAROLD J. LASKI}

The Review has received the following letter from Professor Harold J. Laski concerning his article, Morris Cohen's Approach to Legal Philosophy, I5 Univ. Chi. L. Rev. 575 (I948):

In your summer issue, you were good enough to publish an article of mine on the legal philosophy of the late Professor Morris R. Cohen. In that article, I cited the writings of Judge Jerome Frank as an example of the trend towards anti-intellectualism in "realist" jurisprudence to which Professor Cohen was strongly opposed. Judge Frank has written to me to say that he thinks I do him serious injustice in ascribing to him an anti-intellectualist attitude; he refers me, moreover, to a large number of his articles to which I have no access here. But I am sure that Judge Frank is right and that I must be wrong. I should be grateful, therefore, if you would, at some appropriate place in your next issue, express the regret I feel at having placed Judge Frank's legal philosophy into a category to which he does not think it belongs. 